\title{
THE INFLUENCE OF WORK MOTIVATION AND THE WORK ENVIRONMENT ON EMPLOYEE PERFORMANCE IN FACULTY AGRICULTURE UNIVERSITY NORTH SUMATRA
}

\author{
Osman Manalu \\ STIE STINDO Medan \\ Email: osmanmanalu1@gmail.com \\ Sutaryat Trisnamansyah \\ Universitas Islam Nusantara (UNINUS) Bandung \\ Email: yatsutaryat@ymail.com \\ Husen Saeful Insan \\ Universitas Islam Nusantara (UNINUS) Bandung \\ Email: huseninsan@gmail.com \\ Waska Warta \\ Universitas Islam Nusantara (UNINUS) Bandung \\ Email: waskawarta@gmail.com
}

\begin{abstract}
This study aims to explain the effect of work motivation and work environment variables simultaneously and partially on Employee Performance at the Faculty of Agriculture, University of North Sumatra. The research method used quantitative models, using a questionnaire as a means of collecting data distributed to 50 employees at the Faculty of Agriculture, University of North Sumatra. The research method used is a quantitative method through an associative approach. Research location of the Faculty of Agriculture, University of North Sumatra. The sample selection method in this research is saturated sample (census). The data analysis technique used the classical assumption test, multiple linear regression test, $\mathrm{f}$ test and $\mathrm{t}$ test. The results of this study indicate: 1 ) Work motivation and work environment simultaneously influence employee performance. 2) Partially work motivation has a positive and significant effect on employee performance. 3) The work environment has a positive and significant effect on employee performance. The implication of this research is that observers of cleanliness and observers of work space so that the tasks given by employees are done well and it is hoped that with work motivation will increase the passion and enthusiasm of employees in an organization
\end{abstract}

Keywords: Work Motivation, Work Environment and Employee Performance.

\section{A. INTRODUCTION}

Even in a government organization, it is necessary to develop procedures for developing reliable employee performance. For example in government, many programs are implemented under the direction of superiors or heads of departments but do not make good performance a top priority. Resulting in less than optimal results, resulting in a mismatch between orders and the work being performed. This is also a highlight that must 
be paid attention to by the government, given that the government is the biggest asset of society in improving the welfare of society.

The above is connected with activities in the organization / government, officials or employees of an organization will carry out their work if it is well organized. Therefore, even the superiors or leaders of the organization must really pay attention to employees properly by providing various directions in carrying out organizational work in order to create qualified employees.

The quality of human resources to improve the quality of the organization is controlled in several ways, and one of the ways that is widely used by organizations is through job performance or performance appraisals. Work performance appraisal can be done once a month, once a year, or even every day. Assessment of work performance provides a way for superiors to find out about problems that arise in employees. The results of the performance appraisal help superiors know that the motivations must be used so that employee performance can increase and work diligently for the progress of the organization concerned. Although supported by facilities and infrastructure as well as excessive funding sources, without the support of reliable human resources organizational activities will not be resolved properly.

The success of the organization is influenced by the individual performance of its employees. It is not surprising that human resources are also seen as a valuable asset in the organization and also have a big role in developing organizational governance. Every organization always tries to develop employee performance in the hope that what the organizational goals will be achieved. For example, by means of training, education, providing good compensation, providing motivation, and creating a decent work environment.

Thus, what is considered to affect the performance of employees at the Faculty of Agriculture, University of North Sumatra is the work environment and work motivation. The work environment is everything that is around the worker and which can affect him in carrying out the assigned tasks. The work environment can affect employee morale, enthusiasm and can improve employee performance.

According to Hanaysha, work environment indicators: (1) The facilities to do work, namely facilities that support the task of performing work. (2) Comfortable work place, which is a clean and pleasant work environment. (3) Safety, namely being in a safe and secure state (4) Absence of noise, namely a quiet work environment (Hanaysha, 2016. p.96).

From the results of observations, work motivation at the Faculty of Agriculture, University of North Sumatra is recognition, which is recognition or appreciation given to employees for work results. At the Faculty of Agriculture, University of North Sumatra, giving recognition or appreciation to employees for their work results is not optimal. There is no reward yet given to employees who have good performance in order to increase motivation to do their work better.

The second factor affecting employee performance is work motivation. Motivation is the driving force which results in a member of the organization willing and willing to mobilize 
abilities in the form of expertise or skills, energy and time to carry out various activities that are their responsibility and fulfill their obligations /

Based on the description above, the researcher is interested in conducting a research entitled "The Effect of Work Motivation and Work Environment on Employee Performance at the Faculty of Agriculture, University of North Sumatra".

\section{B. METHOD}

The method used in this research is descriptive research with a quantitative approach that aims to reveal what it is. According to Arikunto, he revealed that descriptive research was not intended to test certain hypotheses, but only described what it is about a variable (Arikunto, 2005. p. 26). According to Arikunto, with quantitative research, many are required to use numbers, starting from data collection, interpretation of the data, and the appearance of the results. So it can be concluded that quantitative descriptive research in this research is to see, review and describe in numbers about the object under study as it is and draw conclusions about it according to the phenomena that appear at the time the research was conducted. (Arikunto, 2006. p. 12).

According to Rusiadi, Subiantoro and Hidayat. Associative / quantitative research is a study that aims to determine the degree of relationship and the pattern / form of influence between two or more variables, where this research will build a theory that functions to explain, predict and control a symptom "(Rusiadi dkk., 2016. p. 12).

The place for researchers from the Faculty of Agriculture, University of North Sumatra, who is located at Jalan Prof. A. Sofyan No.3. USU Campus, Medan 20155.

Population is the entire area of individuals, objects, symptoms or events for a generalization or a conclusion that is put forward (Hadi, 2014. p.53). The population of this research is 50 employees at the Faculty of Agriculture, University of North Sumatra. The sample is a part or representative of the population studied. If the subject is less than 100 , it is better to take all of them, so that the researcher is a population study. If the number of subjects is greater than 100 it can be taken $0 \%$ to $15 \%$ or $20 \%$ or more (Sugiyono, 2010. p. 135 ).

Based on the definition above, the authors took a sample population of all employees at the Faculty of Agriculture, University of North Sumatra, totaling 50 people, so this research is called census research..

\section{RESULTS AND DISCUSSION}

\section{Employee performance \\ Definition of Employee Performance}

Every employee in the organization is required to make a positive contribution through good performance, considering that organizational performance depends on the performance of its employees (Gibson, 2015. p.364). Performance is the level at which employees achieve job requirements efficiently and effectively (Henry, 2015. p.34). Employee performance is work performance, namely the comparison between work results that can be seen in real terms with the work standards set by the organization. 
Then Mangkunegara performance of work results both in quality and quantity achieved by an employee in carrying out tasks in accordance with the responsibilities assigned to him (Mangkunegara, 2015. p.67). Meanwhile according to Kasmir (2018: 182) performance is the result of work and work behavior that has been achieved in completing duties and responsibilities given in a certain period (Kasmir, 2016).

Based on the definitions of performance, some of the opinions above, it is concluded that performance is the result of work both in quality and quantity that employees have achieved in carrying out their duties, in accordance with the responsibilities given by the organization, and the work results are adjusted to the work results expected by the organization through the criteria or employee performance standards that apply in the organization.

According to Rivai, employee performance objectives:

1) To improve employee performance results, both in quality and quantity.

2) Provide new knowledge which will assist employees in solving complex problems, with a limited and regular series of activities, through tasks according to the responsibilities given by the organization.

3) Improve relationships between employees' personal in work activities within the organization (Rivai, 2010. p.549).

Factors Affecting Performance

The factors that affect the performance of both results and work behavior according to Kasmir:

1) Abilities and Skills

2) Knowledge

3) Work Design

4) Personality

5) Work Motivation

6) Leadership

7) Leadership Style

8) Organizational Culture

9) Job Satisfaction

10) Work Environment

11) Loyalty

12) Commitment

13) Work Discipline (Kasmir, 2018. p.191)

\section{Employee Performance Indicators}

According to Kasmir, measuring employee performance can be used several performance indicators, namely; quality, quantity, timeliness, cost effectiveness, need for supervision, and interpersonal relationships. This indicator will be the benchmark in measuring employee performance (Kasmir, 2018. p.208-210).

The explanation of each of the dimensions above:

1) Quality (quality)

2) Quantity (amount)

3) Time (period)

4) Cost Emphasis 


\section{5) Supervision}

6) Relationships between employees

This opinion says that in order to get optimal employee performance which is the goal of the organization, it must pay attention to aspects of work quality, timeliness, initiative, ability and communication.

\section{Work motivation; Definition of Work Motivation}

Motivation is a process that begins with a need in humans that creates emptiness in a person (Chukwuma \& Obiefuna, 2014. p.75). Motivation is a process in which needs encourage a person to carry out a series of activities that lead to the achievement of certain goals. Goals that, if successfully achieved, will satisfy or fulfill these needs (Munandar, 2011. p.48).

In a general sense, motivation as a need that encourages action towards a specific goal. Work motivation is something that creates enthusiasm or work motivation. Therefore, work motivation in work psychology is usually called a morale booster. The strength and weakness of the work motivation of a worker also determines the size of his achievement (Anoraga, 2014. p.58).

Motivation is one of the most important factors influencing human behavior and performance. Motivation theory has been discussed and conceptualized by various researchers. The level of motivation of an individual or team is given in their task or job which can affect all aspects of organizational performance.

Based on several opinions expressed by experts, it can be concluded that work motivation is a process in which the need encourages a person to carry out a series of activities that lead to the achievement of certain goals and organizational goals and to meet several needs. The strength and weakness of the work motivation of a worker also determines the size of the achievement.

Aspects of Work Motivation

Munandar describes the aspects of work motivation:

1) There is discipline from employees

2) Confidence

3) Resistance to pressure (Munandar, 2011. p.95)

Factors affecting Work Motivation

Fredick Hezberg, et al in Wirawan suggest the factors that influence work motivation:

1) Motivation Factor:

2) Health factor (Wirawan, 2013. p.71)

Wirawan suggests other factors regarding motivation, namely:

1) Supervise

2) Interpersonal relationships

3) Physical working conditions

4) Salary

5) Company policies and practices

6) Job benefits and securities (Wirawan, 2013. p.141) 
Based on several opinions expressed by experts, it can be concluded that the factors of work motivation are: supervision, interpersonal relationships, salary, needs, desires, job satisfaction, the resulting work performance..

Work Motivation Indicators

Wibowo, the dimensions and indicators of motivation are as follows:

1) Need for achievement:

a) Target work

b) Quality of work

c) Responsibility

d) Risk

2) The need to expand associations

a. Communication

b. Friendship

3) The need to master a job
a) Leader
b) Company ambassadors
c) Exemplary (Wibowo, 2011. p.162)

The author's opinion from the above understanding that work motivation is a skill in directing or controlling and moving someone to take action on the desired behavior based on targets that have been set to achieve certain goals.

\section{Work environment; Definition of Work Environment}

The work environment is everything that is around the workers that can affect them in carrying out the tasks they are assigned to.

Another case, Sedarmayanti argues that a place has a group in which there are several supporting facilities to achieve company goals in accordance with the company's vision and mission (Sedarmayanti, 2011. p.23).

From some of the opinions above, it can be said that the work environment is everything that is around the employee at work, both physical and non-physical, which can affect him in carrying out his daily duties and work..

\section{Types of Work Environment}

In an effort to plan a work environment, it is necessary to study and determine the aspects forming the work environment itself.

Siagian states that broadly speaking, the work environment is of two types:

1) Physical Work Environment

Physical work environment is all physical conditions that exist around the workplace and can affect employees. There are several physical conditions of a good workplace.

2) Non-Physical Work Environment

A non-physical work environment is a pleasant work environment in the sense of creating a harmonious working relationship between employees and superiors, 
because in essence humans are not only looking for money, but work is a form of activity that aims to get satisfaction (Sondang, 2012. p.57).

Work Environment indicator

Siagian (2014: 61) indicators of the work environment in the company are divided into two dimensions, namely: the physical work environment and the physical work environment (Sondang, 2012. p.61).

1) Physical Work Environment

Physical work environment is all physical conditions that exist around the workplace and can affect employees.

2) Non-Physical Work Environment

Non-physical work environment is the creation of a harmonious working relationship between employees and superiors

From some of the indicators above, the authors conclude that a non-physical work environment can be created well if the relationship between employees and fellow employees is harmonious, and the relationship between employees and superiors is well established as well.

\section{Statistic Test}

In answering problems in a study, it is necessary to describe the characteristics of the data sources, so that the data used to answer these problems is more accurate.

The data obtained during the research will be presented to all employees of the Faculty of Agriculture, University of North Sumatra, as many as 45 civil servants who became respondents. With the total number of questions as many as 30 items, consisting of question items Variable $X$, namely: Work Motivation (X1), and Work Environment (X3), While for variable $Y$, namely: Employee Performance.

\section{Validity Test and Reliability Test}

\section{Validity Test}

The validity test to determine the appropriateness of each questionnaire that has been given to the respondent requires a validity test to measure whether a questionnaire is valid or not.

If each question has a value of $>0.30$ then the question is declared valid (valid).

Based on the Validity Test Result Table, the product correlation coefficient value, the product moment score for each question item with the total of all question items, can be seen in the corrected item total correlation column.

From the data, all coefficient values exceed 0.30 , this can be stated that all the questions and the scores obtained are valid.

Reliability Test 
The reliability test (reliability) determines the stability and consistency of the respondent in answering the items related to the constructs of questions arranged in a questionnaire form. The reliability of a variable construct is said to be good if it has a Cronbach's Alpha value $>0.60$.

Based on the table of reliability test results, it shows that the motivation, work environment, and employee performance variables have a Conbach's alpha value greater than 0.6 . This shows that the question items in this study are reliable. So that each question item used will be able to obtain consistent data and if the question is asked again, an answer will be obtained that is relatively the same as the previous answer.

\section{Data Analysis Technique, Classic Assumption Test and Normality Test}

The normality test aims to test whether it is feasible to use multiple regression, as it is known that the partial effect test assumes that the residural value follows a normal distribution..

\section{Image of Normality Test Histogram}

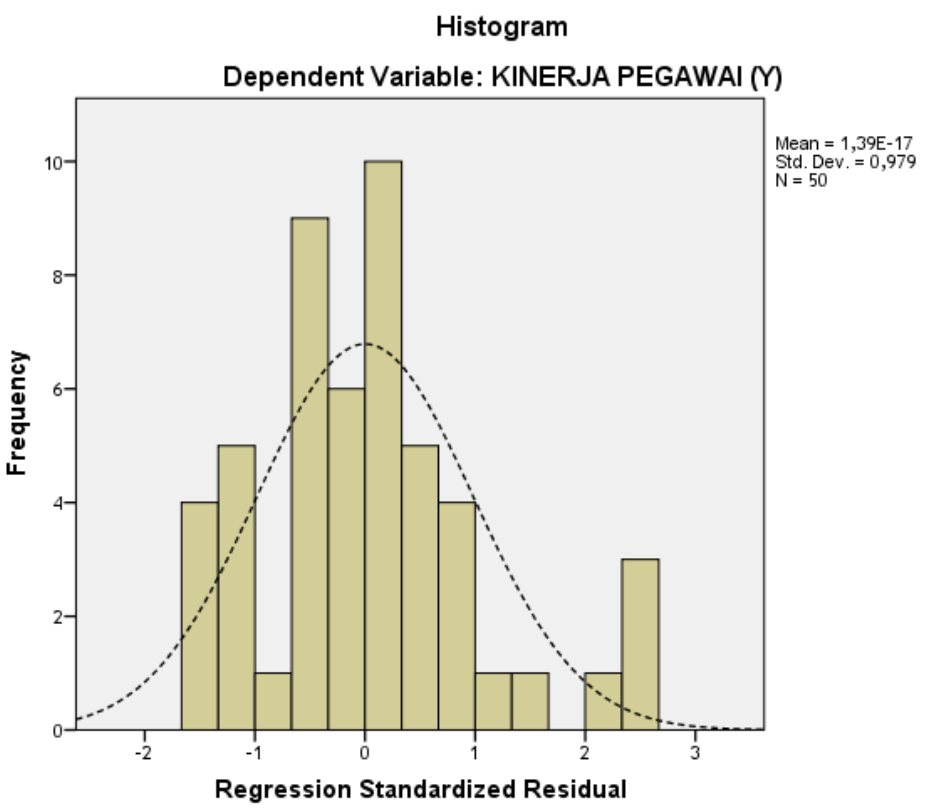

Based on the image of the Normality Test Histogram, the data normality test shows that the data is normally distributed, where the histogram above has a curved line to form like a bell. 
Figure PP Plot Normality Test

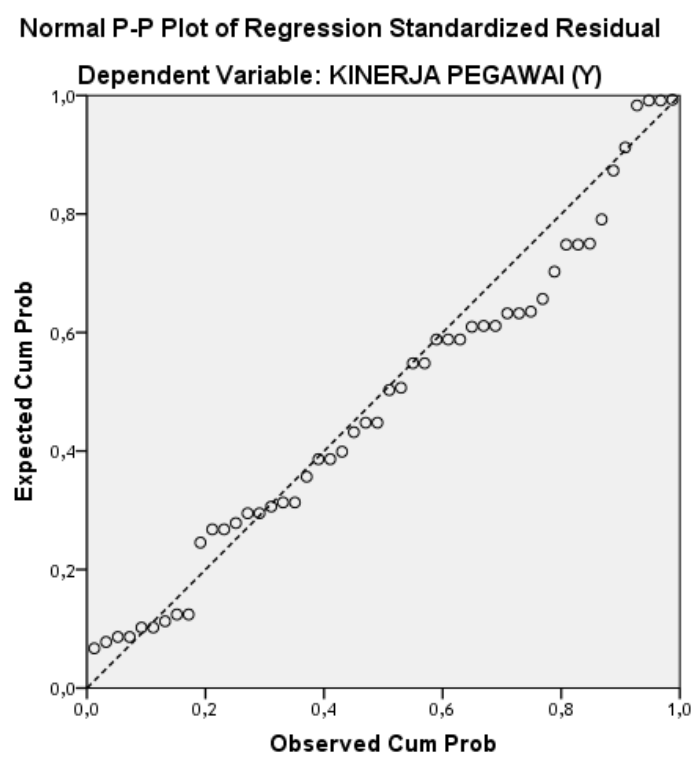

Based on the PP Plot Normality Test Figure, the points spread around the diagonal line, and the direction of the spread follows the direction of the diagonal line. This shows that the regression model is feasible because it meets the assumption of normality.

Uji Multikolinieritas

The cutoff values used to indicate the presence or absence of multicollinearity are:

$$
\begin{array}{ll}
\text { VIF }<10 & =\text { multicollinearity } \\
\text { Tolerance }>0.1 & =\text { no multicollinearity }
\end{array}
$$

Based on the Table of Multicollinearity Test Results, the variables of motivation, work environment, and have a tolerance value above 0.1 and VIF are less than 10 . This means that in the regression equation model there are no symptoms of multicoloniarity so that the data can be used in this study.

Heteroscedacity test

The heteroscedasticity test aims to see whether there is an inequality of variance in the residuals from one observation to another. Heteroscedasticity detection can be done with the scatterplot method where the distribution of the resulting points is formed randomly, does not form a certain pattern and the direction of the spread is above or below the number 0 on the $Y$ axis. The results of the heteroscedasticity test can be seen in the image below.: 
Image of Heteroscedasticity Test Results

Scatterplot

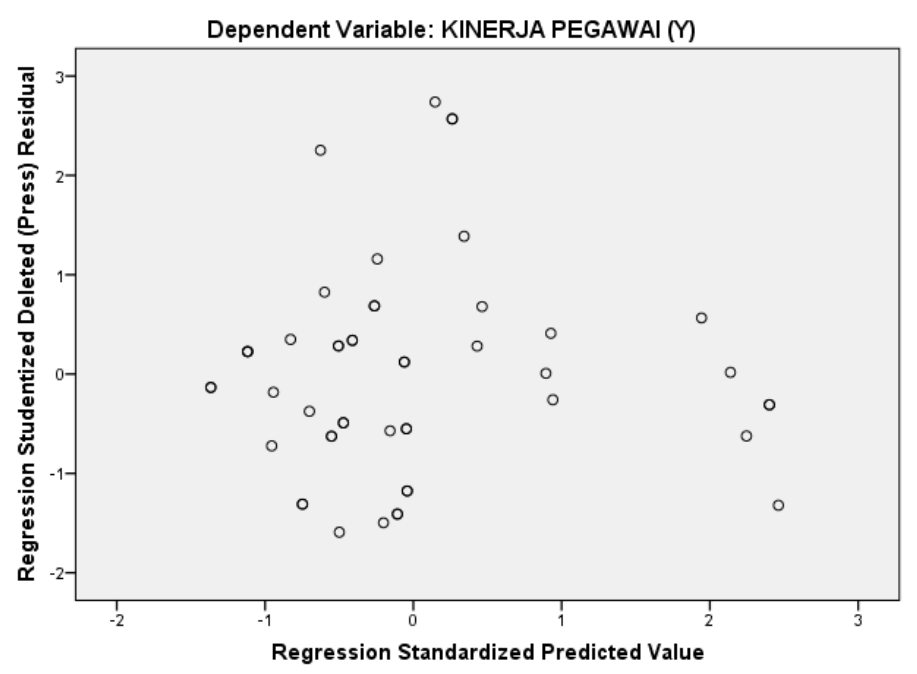

The scatterplot graph shows that the data is spread out on the $Y$ axis and does not form a clear pattern in the distribution of the data. This shows that heteroscedacticity does not occur in the regression model, so that the regression model is suitable to be used to predict employee performance with variables that influence namely motivation, work environment.

\section{Multiple Linear Regression Equation}

A good regression equation model fulfills the requirements of classical assumptions, including all data is normally distributed, the model must be free from multicollenearity symptoms and free from heterocedasticity. The previous analysis proves that this research is considered good. The results from SPSS are used as an analysis tool, the results of multiple regression are as follows:

\section{Multiple Linear Regression Equation Table Coefficients ${ }^{a}$}

\begin{tabular}{|c|c|c|c|c|}
\hline \multirow{2}{*}{\multicolumn{2}{|c|}{ Model }} & \multicolumn{2}{|l|}{\begin{tabular}{|l|l} 
Unstandardized Coefficients \\
\end{tabular}} & \multirow{2}{*}{$\begin{array}{l}\text { Standardized Coefficients } \\
\text { Beta }\end{array}$} \\
\hline & & $B$ & Std. Error & \\
\hline \multirow[t]{3}{*}{1} & (Constant) & 1,795 & ,713 & \\
\hline & WORK MOTIVATION (X1) & ,584 & ,069 &, 576 \\
\hline & WORK ENVIRONMENT (X2) & ,452 & ,072 & ,427 \\
\hline
\end{tabular}

The test results obtained above are as follows:

a. The constant value (a) obtained is 1,795 , meaning that if the motivation variable, the work environment is 0 , then the employee performance level that occurs is 1,795 . 
b. The regression coefficient $X 1=0.584$ means that if the motivation increases by 1 unit, then the employee performance is 0.584 . The direction of motivation on employee performance is positive.

c. The regression coefficient $X 2=0.452$ means that if the work environment is 1 unit, the Employee Performance will increase by 0.452 . The direction of the work environment on employee performance is positive.

\section{Hypothesis test \\ Simultaneous Influence Test (simultant)}

The purpose of the F-Test is calculated to show whether all the independent variables included in the model have joint influence (simultaneously) the independent variable $(X)$ on the dependent variable $(\mathrm{Y})$.

Table of Test Results F

\begin{tabular}{|l|l|r|r|r|r|r|}
\hline \multicolumn{7}{|c|}{ ANOVA $^{\mathrm{a}}$} \\
\hline Model & Sum of Squares & Df & Mean Square & F & Sig. \\
\hline \multirow{3}{*}{1} & Regression & 4541,418 & 2 & 2270,709 & 771,331 &, $000^{\mathrm{b}}$ \\
\cline { 2 - 7 } & Residual & 138,362 & 47 & 2,944 & & \\
\cline { 2 - 7 } & Total & 4679,780 & 49 & & & \\
\hline
\end{tabular}

Based on the F-Test Results Table, the F-test produces an F-value of 771.331 with a significant level of 0.00 . Because Fcount 771.331> Ftable 3.20 and the significant probability is much smaller than 0.05 , namely $0.00<0.05$, the regression model can be said that work motivation and work environment simultaneously have a positive and significant effect on employee performance.

\section{Partial Effect Test}

The test results of the influence of work motivation and work environment variables on employee performance at the Faculty of Agriculture, University of North Sumatra are in the following table:

\section{Tabel Hasil Uji-t Coefficients ${ }^{a}$}

\begin{tabular}{|l|l|c|c|}
\hline \multicolumn{2}{|l|}{ Model } & T & \\
\hline 1 & (Constant) & 2,518 &, 015 \\
\cline { 2 - 4 } & WORK MOTIVATION (X1) & 8,492 &, 000 \\
\cline { 2 - 4 } & WORK ENVIRONMENT (X2) & 6,300 &, 000 \\
\hline
\end{tabular}

The t-test shows how much influence the independent variables individually have on the dependent variable.

The test uses the following steps:

1) Test the Effect of Work Motivation on Employee Performance 
Based on the results table t-test work discipline t count 8.492> t table 1.677 with a significant $0.000<0.05$, meaning that partially work motivation variables have a positive and significant effect on employee performance.

2) Test the Effect of Work Environment on Employee Performance Based on the table of t-test results for the Work Environment, the value of tcount is $6.300>$ ttable is 1.677 with a significant $0.000<0.050$, meaning that partially the Work Environment variable has a positive and significant effect on employee performance..

\section{Coefficient of Determination}

The results of the determination test (R2) can be seen from the coefficient of determination in the following table:

Table of Determination Test Results Model Summaryb

\begin{tabular}{|c|c|c|c|c|}
\hline Model & $\mathrm{R}$ & R Square & Adjusted R Square & Std. Error of the Estimate \\
\hline 1 &, $985^{\mathrm{a}}$ &, 970 &, 969 & 1,716 \\
\hline
\end{tabular}

a. Predictors: (Constant), WORK ENVIRONMENT (X2), WORK DISCIPLINE (X1)

b. Dependent Variable: WORK ACHIEVEMENT (Y)

Based on Table 4:37 the adjusted coefficient of determination (R Square) of 0.969 means that the variation that occurs in variable $Y$ (Employee Performance) is $96.9 \%$ determined by the motivation variable and the rest of the work environment is $3.1 \%(100 \%-96,9 \%)$ is determined by other factors such as work discipline, job stress, achievement, and other factors that are not included in this study..

\section{CONCLUSSIONS}

This study aims to determine the effect of work motivation and employee work environment on employee performance at the Faculty of Agriculture, University of North Sumatra. Based on the description of the research results and discussion, it can be concluded from the research that:

1. Simultaneous research results show that the $F$ test results in an $F$ value of 771.331 with a significant level of 0.00 . Because Fcount $771,331>$ Ftable 3.20 and the significant probability is much smaller than 0.05 , namely $0.00<0.05$, the regression model can be said that work motivation and work environment simultaneously have a positive and significant effect on employee performance.

2. The results of the study that partially work discipline variables $t$ count $8.492>t$ table 1.677 with a significant $0.000<0.05$, meaning that partially work motivation variables have a positive and significant effect on employee performance.

3. The results of the study are partially the Work Environment variable, the value of tcount is $6.300>t$ table 1.677 with a significant $0.000<0.050$, meaning that partially the Work Environment variable has a positive and significant effect on employee performance 
The results of this study indicate work motivation and work environment simultaneously influence employee performance at the Faculty of Agriculture, University of North Sumatra. Partially work motivation and work environment have a positive and significant effect on employee performance, while the variable that has the most dominant influence is work motivation. So this research provides suggestions:

1. Motivation for employees of the Faculty of Agriculture, University of North Sumatra can increase employee morale in an organization, by providing rewards to employees who excel in various activities such as: Morning Apples, Gymnastics and Sports, being present on time. The leadership will also give direct warnings or warnings to employees who are considered undisciplined and do not implement the rules that have been made and regulated by the leadership in accordance with the applicable regulations.

2. The working environment at the Faculty of Agriculture, University of North Sumatra requires attention to cleanliness and attention to the workspace so that employees can do their jobs well. Facilities obtained by employees are not comparable and do not get good comfort, such as less cold air conditioning, less bright room lights, all of which are very influential for the employee's mood in doing their job.

3. Employees are expected to have the achievement of employee performance to improve service quality at the Faculty of Agriculture, University of North Sumatra.

\section{References}

Anoraga. (2014). Psikologi Kerja. Rineka Cipta.

Arikunto, S. (2005). Prosedur Penelitian Suatu Pendekatan Praktek. PT Rineka Cipta.

Arikunto, S. (2006). Metode Penelitian Kualitatif. Bumi Aksara.

Chukwuma, \& Obiefuna. (2014). Effect of Motivation on Employee Productivity: A Study of Manufacturing Companies in Nnewi. Journal of Managerial Studies and Research, 7(2).

Gibson. (2015). Organisasi dan Manajemen, Perilaku, Struktur, dan proses (J. Wahid, Penerj.). Erlangga.

Hadi, S. (2014). Metodologi Research 2. Andi Offset.

Hanaysha. (2016). Testing The Effects of Food Quality, Price Fairness and Phisical Environment on Customer Satisfaction in Fast Food Restaurant Industry. Journal of Asian Business Strategy, Vol. 6 Issue.2(Issue 2), 31-40.

Henry, S. (2015). Manajemen Sumber Daya Manusia. STIEY.

Kasmir. (2016). Aplikasi Analisis Multivariate dengan Program IBM SPSS19. Badan Penerbit Universitas Diponegoro.

Kasmir. (2018). Manajemen Sumber Daya Manusia (Teori dan Praktik). PT Raja Grafindo Persada.

Mangkunegara. (2015). Evaluasi Kinerja SDM. Refika Aditama.

Munandar. (2011). Psikologi Industri dan Organisasi. UI Press.

Rivai. (2010). Performance Appraisal, sistem yang tepat untuk menilai kinerja karyawan dan meningkatkan daya saing perusahaan. PT Raja Grafindo Persada. 
Rusiadi, Subiantoro, Nur, \& Muhammad. (2016). Metode Penelitian: Manajemen, Akuntansi dan Ekonomi Pembangunan. Konsep, Kasus dan Aplikasi SPSS, Eviews, Amos, Lisrel. USU Press.

Sedarmayanti. (2011). Manajemen Sumber Daya Manusia, Reformasi Birokrasi Manajemen Pegawai Negeri Sipil. Rafika Aditama.

Sondang, P. S. (2012). Manajemen Sumber Daya Manusia. Bumi Aksara.

Sugiyono. (2010). Metode Penelitian Pendidikan Pendekatan Kuantitatif, kualitatif, dan R\&D. Alfabeta.

Wibowo. (2011). Manajemen Kinerja. Rajawali Press.

Wirawan. (2013). Evaluasi Kinerja Sumber Daya Manusia. Salemba Empat. 